\title{
EFFECTS OF VISIBLE LIGHT UPON UV-TREATED CONIDIA OF ASPERGILLUS SOJAE
}

\author{
CHIYOKO TAKEICHI \\ Division of Microbial Genetics, Institute of Applied Microbiology, \\ University of Tokyo \\ Received for publication, Oct. 26, 1960
}

\section{INTRODUCTION}

There are three phases in the life cycle of Aspergillus oryzae and Asp. sojae; i.e. haploid, heterocaryon, and heterozygous diploid. It was discovered by the present author (1) that the heterocaryons irradiated by ultraviolet light (UV) gave rise to heterozygous diploids and the heterozygous diploids irradiated by UV gave somatic segregants in higher frequencies. The present work concerns the relationship between the above mentioned two UV effects and the so-called inactivation (killing) effect. Haploid, heterocaryotic, and diploid conidia of Asp. sojae were exposed to visible light immediately after UV irradiation. As to the inactivation effect, the phenomenon of photorecovery (2) is known to occur among many microorganisms.

\section{METHODS AND MATERIALS}

\section{Strains}

The following seven mutants of Asp. sojae K.S. were employed. L-120 yellow leucineless $(y$ leu $), \mathrm{K}-271$ yellow thiamineless $(y$ thi), K-94 yellow paminobenzoic acidless $(y$ pab), K-146 yellow nicotinic acidless $(y$ nic), K-7 yellow methionineless $(y$ meth), H-158 albino histidineless (al his) K-1012 albino arginineless (al arg).

\section{Media}

Media employed in this work are the same as those described in a previous paper (3); minimal medium (MM) is CzAPEK's agar and complete midium (CM), koji-extract agar.

\section{Light Sources}

Ultraviolet light: A 15-watt germicidal lamp (Matsuda, GL-form) was used, of which 95 per cent of the emitting light is of $2,537 \AA$ wave length, where the light intensity at a distance of $37 \mathrm{~cm}$ and at a current of $0.30 \mathrm{~A}$ stands for $22.5 \mathrm{ergs} / \mathrm{mm}^{2} / \mathrm{sec}$ on the surface of conidial suspension.

Visible lights: (i) Black light fluorescence lamp (Matsuda, FL-20 BLB), emitting waves of $3,200-4,000 \AA$, with a peak at $3,600 \AA$. (ii) Day light type

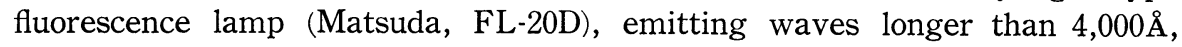


with peaks at $4,600 \AA$ and $5,800 \AA$.

Filters: (i) Glass filter (Matsuda, V-Y3C) which transmits waves above $3,950 \AA$. (ii) Interference filter (Shonan Optical Film) which cuts off radiation at $4,360 \AA$.

For convenience, the following symbols are employed. BL, black light fluorescence lamp; D, day light fluorescence lamp; IF, interference filter; VY, glass filter; and + , with filter.

\section{Definition}

Percentage of survival: Conidial suspension containing about $5 \times 10^{5} \mathrm{co}-$ nidia in one $\mathrm{ml}$ sterile water was exposed to ultraviolet light in a dark room, and aliquots were withdrawn at intervals. Plating was made under a yellow lamp onto $\mathrm{CM}$ in quadruplicate. Survival fractions were determined by counting colonies appearing on CM after 40-48 hours' incubation.

Percentage of photoreactivation: Fractions of reactivated conidia by visible light was estimated from the formula, $100 \times\left(N_{L}-N_{D} / N_{o}-N_{D}\right)$. $N_{o}$ is the number of survivors before UV irradiation, $N_{D}$ (dark survival) the number of survivors after UV irradiation, and $N_{L}$ (light survival) the number of survivors after treatment with visible light. Degree of relative recovery by visible light is to be expressed as $N_{L} / N_{D}$.

Percentage of diploids: When heterocaryotic conidia are plated on MM with or without UV irradiation, there appear three kinds of colonies; (i) colonies covered with green conidia (whole green colonies), (ii) colonies with green sectors or spots (sectored green colonies), and (iii) ordinary heterocaryotic colonies with yellow and white sectors, but with no green sectors. Among the three, the first and the second types were considered to be diploids, and their percentages are recorded. Criteria of a diploid strain were given previously (4).

Percentage of segregants: When conidia arising from a heterozygous diploid are plated on $\mathrm{CM}$, there appear the following five kinds of colonies; (i) green colonies with small yellow spots or sectors $(G+(Y))$, (ii) green colonies with small white spots or sectors $(\mathrm{G}+(\mathrm{Al})$ ), (iii) yellow colonies $(\mathrm{Y})$, (iv) white colonies $(\mathrm{Al})$, and $(\mathrm{v})$ whole green colonies $(\mathrm{G})$. Considering that the first four types are somatic segregants, their percentages are recorded.

\section{RESULTS}

\section{Effects of Visible Light upon Survival of $U V$-treated Conidia.}

Haploid conidia of strain L-120 y leu were exposed to UV for various periods, and subsequently treated by visible light (BL and D lamps) for 30 minutes at a distance of $37 \mathrm{~cm}$. Fig. 1 shows the survival curve and the degree of relative recovery by visible light. Generally speaking, the degree of relative recovery increased with UV dosage, attaining to the maximum at the dosage of five minutes' irradiation $\left(6750 \mathrm{ergs} / \mathrm{mm}^{2}\right)$, where the percentage of survival was about 0.5 . 
In the second experiment, the effect of visible light upon UV-inactivated conidia was examined under the same conditions as in the first experiment, that is, five minutes' UV irradiation and 30 minutes' visible light illumination. Table 1 shows results of five independent experiments, where, as visible light sources, BL and D lamps were employed with or without filters. The data were examined statistically, and it was concluded that visible light could reactivate UV-damaged conidia significantly. The two filters, VY and IF,

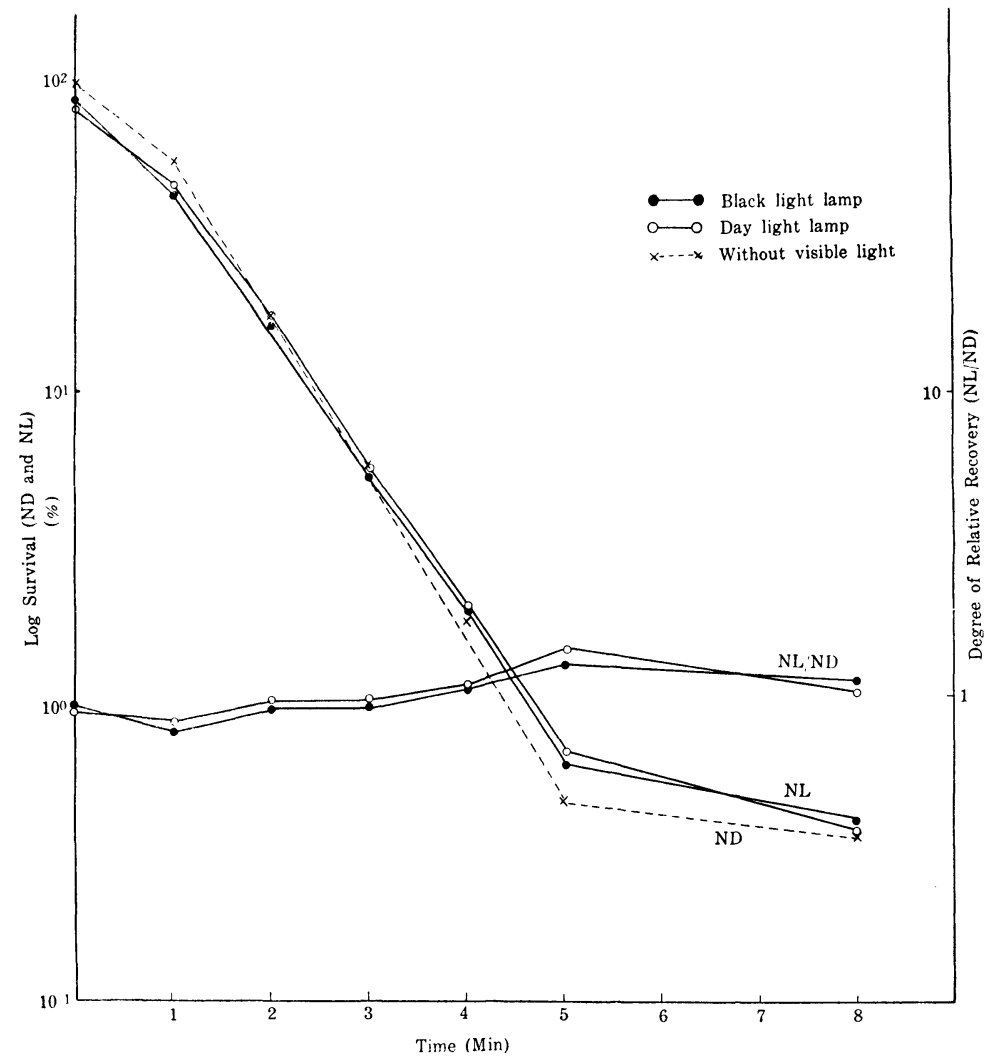

Fig. 1. Effects of Visible Light (Black-and Day-light lamps) upon Survival and Degree of Relative Recovery of UV-treated Conidia (Strain L-120 y leu).

were used to cut off waves below $4,000 \AA$, but no remarkable differences were found in their employment. Similar experiments were carried out by the use of haploid conidia of strain K-7 y meth, and the same conclusion was drawn.

2. Effects of Visible Light upon Diploidization of UV-treated Conidia.

Preliminarily, frequencies of spontaneous diploidization were examined by using seven kinds of heterocaryons (Table 2). As seen in the last column, 
Table 1. Effects of Visible Light upon Survival of UV-treated Conidia. (Strain L-120 y leu)

\begin{tabular}{c|c|c|c|c|c|c}
\hline \multirow{2}{*}{ Exp. No. } & \multicolumn{5}{|c}{ Survival (\%) $\begin{array}{c}\text { after Treatment with Visible Lights } \\
\text { of UV-treated Conidia }\end{array}$} \\
\cline { 2 - 7 } & None & BL* & BL+VY & D & E+VY & D+IF \\
\hline I & 0.40 & 0.43 & 0.44 & 0.47 & 0.50 & 0.43 \\
II & 0.49 & 0.72 & 0.61 & 0.63 & 0.58 & 0.61 \\
III & 0.50 & 0.70 & 0.79 & 0.80 & 0.79 & 0.80 \\
IV & 0.46 & 0.51 & 0.57 & 0.78 & 0.60 & 0.68 \\
V & 0.44 & 0.65 & 0.57 & 0.74 & 0.62 & 0.72 \\
Average & 0.46 & 0.60 & 0.60 & 0.68 & 0.62 & 0.65 \\
NL/ND* & & 1.30 & 1.30 & 1.48 & 1.34 & 1.41 \\
\% PR* & & 0.14 & 0.14 & 0.22 & 0.16 & 0.19 \\
A** & & 0.05 & 0.05 & 0.055 & 0.045 & 0.058 \\
B** & & 0.14 & 0.14 & 0.22 & 0.16 & 0.19 \\
B/A & & 2.8 & 2.8 & 4 & 3.5 & 3.2 \\
\hline
\end{tabular}

* See text.

** A: Variance of differences in average compared with group "None". B: Difference of average compared with group "None".

Table 2. Frequencies of Spontaneous Diploidization in Seven Heterocaryons.

\begin{tabular}{|c|c|c|c|c|}
\hline \multirow{2}{*}{ Heterocaryons } & \multicolumn{2}{|c|}{ No. of Diploid Colonies } & \multirow{2}{*}{$\begin{array}{c}\text { No. of } \\
\text { Colonies } \\
\text { on MM } \\
\text { Examined }\end{array}$} & \multirow{2}{*}{ of Diploids* } \\
\hline & $\begin{array}{c}\text { Whole Green } \\
\text { Colonies }\end{array}$ & $\begin{array}{c}\text { Sectored Green } \\
\text { Colonies }\end{array}$ & & \\
\hline L-120 y leu $+\mathrm{H}-158$ al his & $\begin{array}{r}8 \\
16\end{array}$ & $\begin{array}{l}2 \\
1\end{array}$ & $\begin{array}{l}4438 \\
2594\end{array}$ & $\begin{array}{l}0.22 \\
0.65\end{array}$ \\
\hline $\mathrm{L}-120$ y leu $+\mathrm{K}-1012$ al arg & 3 & 1 & 2674 & 0.15 \\
\hline $\mathrm{K}-271 y$ thi $+\mathrm{K}-1012$ al arg & $\begin{array}{l}18 \\
20\end{array}$ & $\begin{array}{l}1 \\
2\end{array}$ & $\begin{array}{l}2600 \\
2560\end{array}$ & $\begin{array}{l}0.73 \\
0.86\end{array}$ \\
\hline K-94 y Pab+K-1012 al arg & $\begin{array}{l}0 \\
0\end{array}$ & $\begin{array}{l}1 \\
0\end{array}$ & $\begin{array}{l}2906 \\
2530\end{array}$ & $\begin{array}{l}0.034 \\
0\end{array}$ \\
\hline $\mathrm{K}-146$ y nic $+\mathrm{K}-1012$ al arg & $\begin{array}{l}1 \\
0\end{array}$ & $\begin{array}{l}0 \\
1\end{array}$ & $\begin{array}{l}2880 \\
3005\end{array}$ & $\begin{array}{l}0.034 \\
0.033\end{array}$ \\
\hline $\mathrm{K}-7$ y meth $+\mathrm{K}-1012$ al arg & 12 & 7 & 2718 & 0.7 \\
\hline $\mathrm{K}-7 y$ meth $+\mathrm{H}-158$ al his & $\begin{array}{l}1 \\
0\end{array}$ & $\begin{array}{l}0 \\
1\end{array}$ & $\begin{array}{l}3560 \\
2715\end{array}$ & $\begin{array}{l}0.028 \\
0.037\end{array}$ \\
\hline
\end{tabular}

* See text.

percentage of diploids differed according to the combinations of the strains, showing the maximal value in the combination between $\mathrm{K}-271$ th $i$ and $\mathrm{K}$ 1012 al arg. 
Two heterocaryons, (L-120 yleu $+\mathrm{H}-158$ al his) and (K-7 y meth $+\mathrm{H}-158$ al his), effects of UV irradiation were studied. Conidia harvested from these heterocaryons were exposed to UV for five minutes under conditions described in the foregoing section. As seen in the third column of Table 3 , the UV irradiation enhanced about ten times the frequencies of diploidization.

Next, the UV-irradiated heterocaryotic conidia were exposed to visible light for 30 minutes and plated onto MM under a yellow lamp. As seen

Table 3. Effects of Visible Light upon Diploidization Induced by Ultraviolet Light.

\begin{tabular}{c|c|c|c|c}
\hline \multirow{2}{*}{ Heterocaryons } & & \multicolumn{2}{|c}{$\%$ of Diploids after UV-treatment } \\
\cline { 3 - 5 } & $\begin{array}{c}\text { \% of Diploids } \\
\text { (Spontaneous) }\end{array}$ & $\begin{array}{c}\text { Without Visible } \\
\text { Light } \\
\text { Treatment }\end{array}$ & \multicolumn{2}{|c}{$\begin{array}{c}\text { With Visible Light } \\
\text { Treatment }\end{array}$} \\
\hline L-120y leu+H-158 al his & $0.22^{*}$ & $1.2^{*}$ & $1.3^{*}$ & $1.8^{*}$ \\
& 0.65 & 3.2 & 3.9 & 3.5 \\
K-7y meth+H-158 al his & 0.15 & 2.5 & 2.3 & 1.9 \\
& 0.35 & 4.3 & 5.0 & 4.0 \\
& 0.028 & 0.29 & 0.33 & 0.31 \\
& 0.037 & 0.45 & 0.42 & 0.48 \\
& 0.030 & 0.50 & 0.52 & 0.64 \\
& 0.010 & 0.70 & 0.60 & 0.65 \\
\hline
\end{tabular}

* See text.

Table 4. Effects of Visible Light upon Segregation Induced by Ultraviolet Light.

L-120 y leu/H-158 al his.

\begin{tabular}{|c|c|c|c|c|c|c|c|c|c|c|c|c|}
\hline \multirow{4}{*}{ Segregants } & & & & \multicolumn{9}{|c|}{ Segregation after UV Treatment } \\
\hline & \multirow{2}{*}{\multicolumn{3}{|c|}{$\begin{array}{c}\text { Spontaneous } \\
\text { Segregation }\end{array}$}} & \multirow{2}{*}{\multicolumn{3}{|c|}{$\begin{array}{l}\text { Without Visible } \\
\text { Light Treatment }\end{array}$}} & \multicolumn{6}{|c|}{ With Visible Light Treatment } \\
\hline & & & & & & & \multicolumn{3}{|c|}{$\mathrm{BL}$} & \multicolumn{3}{|c|}{$\mathrm{D}$} \\
\hline & $\underset{I}{\text { Exp. }}$ & II & III & Exp. & II & III & Exp. & II & III & $\underset{\text { I }}{\text { Exp. }}$ & II & III \\
\hline $\mathrm{G} *$ & 603 & 529 & 827 & 630 & 444 & 843 & 787 & 299 & 768 & - & 266 & 770 \\
\hline $\mathrm{G}+(\mathrm{Y})$ & 5 & 4 & 11 & 34 & 24 & 52 & 41 & 18 & 48 & - & 28 & 55 \\
\hline $\mathrm{G}+(\mathrm{Al})$ & 8 & 14 & 26 & 46 & 42 & 65 & 50 & 34 & 63 & - & 29 & 80 \\
\hline $\mathrm{Y}$ & 0 & 0 & 0 & 0 & 2 & 0 & 1 & 4 & 1 & - & 2 & 0 \\
\hline $\mathrm{Al}$ & 1 & 1 & 1 & 1 & 2 & 0 & 0 & 0 & 0 & - & 0 & 0 \\
\hline Totals & 617 & 548 & 865 & 711 & 514 & 950 & 879 & 355 & 880 & - & 325 & 905 \\
\hline $\begin{array}{l}\% \text { of } \\
\text { Segregants }\end{array}$ & 2.3 & 3.5 & 4.4 & 11.2 & 13.6 & 12.3 & 10.5 & 15.8 & 13.7 & - & 18.1 & 14.9 \\
\hline
\end{tabular}


$\mathrm{K}-7 y$ meth/H-158 al his.

\begin{tabular}{|c|c|c|c|c|c|c|c|c|c|c|c|c|}
\hline \multirow{4}{*}{ Segregants } & \multirow{3}{*}{\multicolumn{3}{|c|}{$\begin{array}{l}\text { Spontaneous } \\
\text { Segregation }\end{array}$}} & \multicolumn{9}{|c|}{ Segregation after UV Treatment } \\
\hline & & & & \multirow{2}{*}{\multicolumn{3}{|c|}{$\begin{array}{l}\text { Without Visible } \\
\text { Light Treatment }\end{array}$}} & \multicolumn{6}{|c|}{ With Visible Light Treatment } \\
\hline & & & & & & & \multicolumn{3}{|c|}{$\mathrm{BL}$} & \multicolumn{3}{|c|}{$\mathrm{D}$} \\
\hline & $\underset{I}{\operatorname{Exp}}$ & II & III & $\begin{array}{l}\text { Exp. } \\
\text { I }\end{array}$ & II & III & $\begin{array}{l}\text { Exp. } \\
\text { I }\end{array}$ & III & III & Exp. & II & III \\
\hline G* & 703 & 873 & 807 & 643 & 808 & 995 & 688 & 786 & 953 & - & 630 & 950 \\
\hline $\mathrm{G}+(\mathrm{Y})$ & 12 & 16 & 15 & 60 & 82 & 112 & 44 & 74 & 123 & - & 66 & 118 \\
\hline $\mathrm{G}+(\mathrm{Al})$ & 22 & 29 & 23 & 48 & 63 & 89 & 37 & 49 & 104 & - & 44 & 104 \\
\hline $\mathrm{Y}$ & 0 & 0 & 4 & 2 & 2 & 3 & 1 & 4 & 0 & - & 8 & 2 \\
\hline $\mathrm{Al}$ & 0 & 0 & 2 & 0 & 3 & 1 & 1 & 0 & 0 & - & 1 & 1 \\
\hline Totals & 737 & 918 & 851 & 753 & 958 & 1200 & 771 & 913 & 1180 & - & 749 & 1175 \\
\hline $\begin{array}{l}\% \text { of } \\
\text { Segregants }\end{array}$ & 4.7 & 4.9 & 5.2 & 14.5 & 15.7 & 17.1 & 10.8 & 13.9 & 19.2 & - & 16.0 & 19.1 \\
\hline
\end{tabular}

* See text and J. Gen. and Appl. Microbiol. 2, 401-430 (1956).

in the fourth and the fifth columns, no significant increase or decrease of diploidization was observed.

3. Effects of Visible Light upon Segregation of UV-treated Conidia.

Two heterozygous diploids, L-120 y leu/H-158 al his and K-7 y meth/H-158 al his, were employed. As seen in the second column of Table 4, the two diploids gave rise to somatic segregants in percents of 2-5 under natural condition. Meanwhile, when they were irradiated by UV, the percentages increased to $10-17$.

Next, the UV-treated conidia were exposed to visible light for 30 minutes immediately after UV irradiation. However, percentage of segregants was neither enhanced nor reduced; results are shown in Table 4.

\section{DISCUSSION}

Ever since the phenomenon of photorecovery was discovered by KeLNeR (2), it has been studied extensively with fungi $(5,6)$, yeast $(7,8)$, bacteria $(9-13)$, and bacteriophages $(14,15)$. In this paper, evidences that visible light could restore UV-induced damage occasioned in haploid conidia of $A s p$. sojae were presented. In the light of latest knowledge, the finding is not particularly new.

It was demonstrated again that ultraviolet light could enhance frequencies of diploidization and segregation significantly. However, visible light illumination immediately after UV irradiation gave no significance effects upon the frequencies. The only conclusion that the author can draw at the present time is, therefore, that the function of UV resulting in inactivation 
of conidia is different from those resulting in enhancement of diploidization and segregation. Different mechanism may be at work.

At the outset of this work, it was hoped to discern the UV effect on diploidization from the UV effect on segregation by the employment of visible light illumination technique, but, as a matter of fact, no difference was found. Whether or not the mechanism of UV function on diploidization is the same as that on segregation is not yet known. The subject will be studied in future.

\section{SUMMARY}

By using mutants of Aspergillus sojae, it was demonstrated again that the heterocaryons and the heterozygous diploids irradiated by ultraviolet light gave rise to diploids and somatic segregants in higher frequencies. These two effects of ultraviolet light were compared with the so-called inactivation (killing) effect of UV. The haploid conidia inactivated by ultraviolet light were reactivated by visible light, while visible light gave no significant effect on diploidization and segregation. It was concluded, therefore, that the mechanism of UV function on inactivation is different from that on diploidization and segregation. Differences between two functions of UV, on diploidization and on segregation, are not known.

\section{ACKNOWLEDGMENTS}

The author gratefully acknowledges the continued support and criticism of Professor Y. IKedA and the statistical tests of Dr. S. Hitotumatsu.

\section{REFERENCES}

(1) C. Ishitani: Nature 178, 706 (1956).

(2) A. Kelner: Proc. Natl. Acad. Sci. U.S. 35, 73 (1949).

(3) C. Ishitani, Y. IKeda and K. Sakaguchi: J. Gen. and Appl. Microbiol. 1, 272 (1955).

(4) C. Ishitani, Y. IKeda and K. SaKaguchi: ibid. 2, 401 (1956).

(5) A. Kelner: J. Cellular and Comp. Physiol. 39, Suppl. 1, 115 (1952).

(6) A. NoRman: ibid. 44, 1 (1954).

(7) A. SARACHECK: Cytologia 19, 77 (1954).

(8) D. Pittman and P. R. Pedigo: Exp. Cell Research 17, 359 (1959).

(9) A. Kelner: J. Gen. Physiol. 34, 835 (1951).

(10) H. Berger, F. L. Hass, O. Wyss and W. S. Stone: J. Bact. 65, 538 (1953).

(11) W. D. Bellamy and M. T. GermaIN: ibid. 70, 351 (1955).

(12) J. H. StuY: Biochem. and Biophys. Act. 17, 206 (1955).

(13) C. R. Goucher, I. KAMeI and W. Kocholaty: J. Bact. 72, 184 (1956).

(14) R. DulbeCo: Nature 163, 949 (1949).

(15) R. DUlbeCo: J. Bact. 59, 329 (1950). 